\title{
Acquisition of spatial adjectives in the case of a four- year-old child knowing Azerbaijani Turkish, English and Farsi: A case study of multilingualism
}

\author{
Mostafa Shahiditabar \\ Imam Sadiq University, Iran
}

\section{INTRODUCTION}

The process that describes the acquisition of the capacity of humans to perceive and comprehend language is language acquisition which occupies a crucial role in linguistics and psycholinguistics. The study of spatial adjectives acquisition as an integrated part of language acquisition has gained a remarkable attention of language scholars. Clark (Clark, 1972)'s hierarchy of acquisition for spatial adjectives is one of the best samples of this kind. Clark (Clark, 1972)'s hierarchy of acquisition for spatial adjectives includes big/little, tall/short, long/short, high/low, wide/narrow and thick/thin, respectively. This study aims at considering acquisition of spatial adjectives in a multilingual child. More specifically, the current study strives to answer the following research questions:

Research questions

1. To what extent do the results of this study confirm Clark (Clark, 1972)'s hierarchy of acquisition for spatial adjectives?

2. What similarities and differences can be seen in spatial adjective acquisition in Azerbaijani Turkish, English and Farsi?

3. Which adjective pair proves easiest for the child?

4. Does the subject give inappropriate responses, how inappropriate are they? 


\section{REVIEW OF LITERATURE}

According to the review of literature, Tribushinina (Tribushinina, 2013) considers spatial adjectives in Dutch child language towards a usage-based model of adjective acquisition. She examines three acquisitions of spatial adjectives hypotheses namely semantic feature hypothesis, haphazard example hypothesis, and best exemplar hypothesis - against longitudinal data from Dutch and finds out that specific adjective-noun/object pairings are stored by children and are caused to play the same role as communicative function in their language from the input. She also believes that the mentioned factor justifies why relative frequencies of spatial adjectives in child speech are strongly correlated with child-directed speech and why children often use spatial adjectives to express contrast.

Aksu-Koç (Aksu-Koç, 2011) studies the acquisition of adjectives in Turkish and explores the adjectives emergence in language. This study is nearly related to the current study, since both papers explore Turkish. Of course, our study focuses on Azerbaijani Turkish (the language spoken primarily by the Turks in Iran, Azerbaijan republic etc) rather than Turkish (the language spoken primarily by the Turks in Turkey) on the one hand and it considers a multilingual child rather than a monolingual case on the other hand.

Barner \& Snedeker (Barner \& Snedeker, 2008) scrutinizes compositionality and statistics in adjective acquisition in 4-year-olds. This study is also related to our study, since both studies explore 4-year-olds. Of course, our study is a case study, while, Barner \& Snedeker (Barner \& Snedeker, 2008) is not a case study.

Harris, Morris, \& Terwogt (Harris, Morris, \& Terwogt, 1986) examine the early acquisition of spatial adjectives (big, tall, and long) between 3- to 4year-old and 4- to 5-year-old English children. Comprehension of three mentioned adjectives improves as the children age according to Harris, Morris, \& Terwogt (Harris, Morris, \& Terwogt, 1986). This work discusses the implications of the findings for the acquisition of spatial adjectives as well as for theories of semantic development. 


\section{METHODOLOGY}

\section{Subject}

The subject of the current study is the researcher's first child, Morteza. He has been exposed to Azerbaijani Turkish, English and Farsi from birth. His father and his uncle who are not native speakers of English (his father is an English language instructor and his uncle is an engineer who has learned English as a foreign language) are planned to talk in English with him. One of his aunts is planned to talk in Farsi with him and the rest of his family including his grandparents are planned to talk in Azerbaijani Turkish with him.

\section{Procedure}

The opposite game is played for understanding of spatial adjectives of the subject. For this, two glove puppets named Buzz and Woody are showed to the subject. The subject is informed that Woody always says the opposite of what Buzz says. It is demonstrated with some easy pairs in all three languages like ağ/qara (white/black) in Azerbaijani, good/bad in English, فشنح/زشت(beautiful/ugly) in Farsi, etc. Then, one of the puppets, for example Woody, is given to the child and an adjective is said while Buzz is kept by the interviewer. The subject gives his intended words that are recorded in appropriate columns. It should be mentioned that all the pairs are run once. Then paired are run again, using the negative number of each pair.

\section{CLARK'S HIERACHY OF ACQUISITION FOR SPATIAL ADJECTIVES}

Clark (Clark, 1972)'s hierarchy of acquisition for spatial adjectives is shown in the following table that starts from big/little pair and ends with deep/shallow pair.

Table 1. Order of acquisition for spatial adjectives according to Clark with Azerbaijani Turkish and Farsi equivalents 


\begin{tabular}{|c|c|c|}
\hline English adjectives & $\begin{array}{l}\text { possible Azerbaijani } \\
\text { Turkish equivalent }\end{array}$ & $\begin{array}{l}\text { possible Farsi } \\
\text { equivalent }\end{array}$ \\
\hline big/little & böyük /kiçik & بزرگ// كوجى \\
\hline tall/short and & uca/alçaq & بلند/ كوتاه \\
\hline long/short & uzun/ güdə & در از/كوتاه \\
\hline high/low & uca/ alçaq & بلند/ كوتاه \\
\hline wide/narrow & ənli/dar & عريض/باريك \\
\hline thick/thin & qalın/ yuxa & ضخيم/باريك \\
\hline deep/shallow & dərin/dayaz & عميق/كم عمق \\
\hline
\end{tabular}

\section{RESULTS}

The results of this study using the opposite game are seen in the following table in English, Azerbaijani Turkish and Farsi languages.

Table 2. The results of acquisition for spatial adjectives of Morteza

\begin{tabular}{llll}
\hline Adjectives & English & Azerbaijani Turkish & Farsi \\
\hline big/little & small & kiçik & sوجو \\
tall/short & short & kiçik & no answer \\
long/short & no answer & kiçik & no answer \\
high/low & no answer & no answer & no answer \\
wide/narrow & no answer & no answer & نرم \\
thick/thin & small & arıq (araq) &
\end{tabular}

\section{DISCUSSION}

As far as the results are concerned, the subjects answers do not completely agree with Clark (Clark, 1972)'s hierarchy of acquisition for spatial 
adjectives. For instance, the child has produced artq in Azerbaijani Turkish, small in English and كوجولو in Farsi for thin listed in Clark (Clark, 1972)'s hierarchy of acquisition for spatial adjectives as the most difficult adjective to acquire for children. Moreover, the child could not produce any words in the three languages he knew for low which is said to be acquired earlier than thin in Clark (Clark, 1972)'s hierarchy.

One point to be mentioned regarding high/low pair is that Morteza uses up and down to mean high and low. For instance, when he flies his paper plane he says his plane 'flies up' or 'flies down' instead of flies high or flies low. Also, regarding the number of adjectives, the subject has used only two adjectives in the three languages, however, he has used kiçik four times, and each time meant a different adjective as well as arlq once in Azerbaijani Turkish, small twice while short once in English and بزرم twice while once in Farsi. It can be argued that the subject has started to set up semantic fields by grouping words related in meaning (when he uses up and down to mean high and low) even before he learns the complete meanings of some of the words. This finding confirms Clark (Clark, 1972).

Another finding of the study is the fact that big/little and tall/short pairs are easiest pairs for the child to acquire. About the inappropriate responses, the subject has used araq instead of ariq in Azerbaijani Turkish, نرم (means: soft) instead of لاغر in Farsi. Another point regarding the results is the fact that big/little is the pair of adjectives that the subject of the study has acquired in all of the mentioned languages, while wide/narrow is the one that he was not capable to produce any words in the studied languages. It can be concluded that big/little is the earliest set of adjectives for the child to acquire whereas wide/narrow is the latest set for him to acquire.

Regarding what is mentioned, it can be argued that differences in words frequency used by the subject are in fact the result of semantic or cognitive complexity that requires in-depth analysis.

Another interesting point is about the three languages. As mentioned earlier, the subject has been exposed to Azerbaijani Turkish, English and Farsi from birth; Azerbaijani Turkish and Farsi are the first languages of the speakers who talked to the subject, meanwhile, English is not the first language of his father and his uncle rather it is their foreign language. A glance to the results 
show that linguistics backgrounds of the people who talked to the subject have not affected spatial adjectives acquisition.

\section{Answers}

1. The results of the current research do not completely agree with Clark (Clark, 1972)'s hierarchy of acquisition for spatial adjectives.

2. Regarding the number of adjectives, the subject of the study has used only two adjectives in the three languages, however, he has used kiçik four times, and each time meant a different adjective as well as ariq once in Azerbaijani Turkish, small twice and short once in English and كوجولو twice while نرم once in Farsi.

3. Big/little and tall/short pairs prove easiest for the child to acquire.

4. Yes. He has used araq instead of arlq in Azerbaijani Turkish, نرم (means: soft) instead of لاغ in Farsi.

\section{IMPLICATIONS OF THE STUDY}

The findings of the current study are hoped to be helpful for the experts of both child language acquisition and multilingualism studies. Despite the fact that this study is a case study, it is hoped to shed more light on child language acquisition and multilingualism in general and the hypothesis that semantic fields are set up early on by the child in particular. It can be said that some of the main issues in child language acquisition are semantic fields, order of acquisition for spatial adjectives, multilingualism, semantics and cognitive complexity. The findings of the current study have a strategic importance in relation to the mentioned general problems in linguistics.

\section{SUGGESTION FOR FURTHER STUDIES}

This paper studies acquisition of spatial adjectives in the case of a four-yearold child knowing Azerbaijani Turkish, English and Farsi. There are plenty of practical applications for the results of this study. Future work includes acquisition of spatial adjectives in some cases of four-year-old children 
knowing Azerbaijani Turkish, English and Farsi or other languages. Also, it is suggested to choose cases of both genders.

\section{References and notes:}

Aksu-Koç, A (2011) An exploration of the emergence of adjectives in Turkish. In E. E. Taylan \& B. Rona (eds.), Puzzles of language: Essays in honor of Karl Zimmer (pp. 103-120). Wiesbaden: Harrassowitz Verlag.

Barner , D \& Snedeker , J. (2008). Compositionality and Statistics in Adjective Acquisition: 4-Year-Olds Interpret Tall and Short Based on the Size Distributions of Novel Noun Referents. Child Development, 79(3), 594-608.

Clark, E. V. (1972). On the child's acquisition of antonyms in two semantic fields. Journal of Verbal Learning and Verbal Behavior, 11(6), 750758.

Harris, P. L., Morris, J. E. \& Terwogt, M. M. (1986). The early acquisition of spatial adjectives: a cross-linguistic study. Journal of Child Language, 13(2), 335-352.

Stilwell peccei, J. (2006). Child Language. (2nd ed.). New York: Francis and Tayllor.

Tribushinina, E. (2013). Spatial adjectives in Dutch child language: Towards a usage-based model of adjective acquisition. In Paradis, C, Hudson, J \& Magnusson, U (Eds), The Construal of Spatial Meaning: Windows into Conceptual Space (pp. 263-286). Oxford: Oxford University Press. 


\title{
Summary
}

\section{Acquisition of spatial adjectives in the case of a four-year-old child knowing Azerbaijani Turkish, English and Farsi: A case study of multilingualism}

\author{
Mostafa Shahiditabar \\ Imam Sadiq University, Iran
}

This study aims at investigating the acquisition of spatial adjectives in a four-year-old multilingual child speaking Azerbaijani Turkish, English and Farsi. The subject of the current study has been exposed to the mentioned languages from birth. The opposite game is played for the elicitation of the adjectives. The results show that the child's answers are not the same in the three languages. For instance, he could produce kiçik for low in Azerbaijani Turkish but he could not produce the same adjective in English nor Farsi. Furthermore, the results of the current research do not completely agree with Clark (Clark, 1972)'s hierarchy of acquisition for spatial adjectives including big/little, tall/short, long/short, high/low, wide/narrow and thick/thin, respectively. For example, the child could produce ariq in Azerbaijani Turkish, small in English and كوجولو in Farsi for thin listed in Clark (Clark, 1972)'s hierarchy of acquisition for spatial adjectives as the most difficult adjective to acquire by children. Moreover, the child could not produce any words in the three languages he knew for low which is said to be acquired earlier than thin in Clark (Clark, 1972)'s hierarchy.

Keywords: Language acquisition; multilingualism; Azerbaijani Turkish; English; Farsi 